\title{
ARTICLES
}

\section{Why South Sudan's problems stem from the abuse of sovereignty: The case for co-governance}

\author{
Samuel Makinda \\ School of Business and Govemance, Murdoch University \\ S.Makinda@murdoch.edu.au
}

\begin{abstract}
The continuing political crisis in South Sudan has been explained almost exclusively in terms of internal power dynamics. This article goes beyond the domestic focus and examines the manner in which the imbroglio has exposed weaknesses in South Sudan's sovereign statehood. It argues that it was the failure to uphold empirical and popular sovereignty that, in part, precipitated the problem. Therefore, it suggests that a resolution ought to involve a re-examination of the relationship between popular, empirical and juridical sovereignty. This article posits that a renegotiation of South Sudan's sovereignty, involving co-governance, would deliver good governance, strengthen economic management, facilitate state-building, and enhance regional security.
\end{abstract}

\section{Introduction}

As I completed this article in early 2017, ${ }^{1}$ a large section of South Sudan's population was facing serious famine, which partly stemmed from bad governance and the long-running civil war in which many people have been maimed, displaced from their homes or lost their lives (Prendergast 2017). The civil war has created political uncertainty, undermined confidence in the economy and destroyed some public institutions. Despite concerted efforts by leading African and international actors to end the conflict in the United Nation's newest member, which achieved independence in July 2011, there are no indications that South Sudan will

\footnotetext{
${ }^{1}$ Fieldwork was conducted in January and July 2016 in East Africa, which included conversations with journalists, people who have worked with the South Sudanese government, and African as well as western diplomats.
} 
enjoy peace soon. The regional Intergovernmental Authority on Development (IGAD), the African Union (AU), and the United Nations (UN) have been involved in South Sudan's political imbroglio since December 2013. Even the European Union (EU), the United States (US) and China have played various roles in mediating between the warring parties. These intensified diplomatic efforts produced an agreement on the resolution of the conflict in August 2015, but the major political players in the country, including President Salva Kiir and former Vice-President Riek Machar, have not honoured this agreement (IGAD 2015). If the South Sudanese conflict was a human disease, doctors would have concluded that it was not responding to the medicines administered and suggested that those concerned look for a different approach.

Given the severity of the political, economic and humanitarian conditions in South Sudan, why haven't international society ${ }^{2}$ and the country's leadership found a lasting solution? Moreover, given the fact that the UN, the US, the EU, and other international actors have injected huge amounts of resources into South Sudan and yet nothing positive has come out of it, how should international society continue to be engaged with it?

Addressing these questions adequately requires a proper diagnosis of the problems. Based on some of the literature, South Sudanese conflict has been attributed to various domestic factors. For example, de Waal (2014b) has explained the crisis in terms of a militarised and corrupt neopatrimonial system of governance. A little earlier, Johnson (2014) had explained the crisis in terms of the tensions within the ruling Sudan People's Liberation Movement (SPLM) and the Sudan People's Liberation Army (SPLA). In addition, Pinaud (2014) has explained how strategies used by SPLA senior officers to constitute themselves into a new aristocracy, contributed to the generation of the crisis. All three articles are informative, well researched, and insightful. They deal with the impact of neo-patrimonial relations, the lack of transparency and public accountability, and the high level of corruption in the country, which have led to considerable public dissatisfaction with service delivery. In addition, they explain why the crisis is due to various weaknesses, including the

\footnotetext{
${ }^{2}$ As for the definition of the society of states, I refer to Bull (1977: 13) who argued: 'A society of states (or international society) exists when a group of states, conscious of certain common interests and common values, form a society in the sense that they conceive themselves to be bound by a common set of rules in their relations with one another and share in the working of common institutions'. Unless stated otherwise, this is the definition of international society that I use in this article.
} 
absence of transformative leadership, uncertainty over the future leadership of the SPLM, and the mismanagement of the state. At the same time, they rightly dismiss claims that the political imbroglio is predominantly a tribal fight between Kiir's Dinka, the largest ethnic group in the country, and Machar's Nuer, the second largest ethnic group. The above articles shed light on important sources of the crisis, but they are so focused on the internal dynamics that they pay little or no attention to South Sudan's position in the global society of states.

This present article makes an original contribution to the debate on South Sudan's problems through two hypotheses. The first hypothesis is that the most effective way of understanding the political crisis in South Sudan is through an analysis of the leaders' mismanagement and abuse of the country's sovereignty. As a member of international society, South Sudan has certain responsibilities, and its political leaders are expected to respect international norms, rules and institutions, including sovereignty and human rights. This article takes into account the internal power dynamics addressed by de Waal (2014a), Johnson (2014), and Pinaud (2014), but it posits that most of South Sudan's continuing problems cannot be explained fully without reference to the abuse of sovereignty. There have been consistent and widespread attempts by South Sudan's leaders to abuse the bases of sovereignty when they are expected to respect them. The second hypothesis is that South Sudan's sovereignty could be resuscitated only through co-governance for a specified period. Co-governance would involve South Sudan and international society, including the UN and the AU, but it is not a form of neo-colonialism. A former US Special Envoy for South Sudan, Princeton Lyman, and a former director of USAID in South Sudan, Kate Almquist Knopf, have expressed similar views (Lyman and Knopf 2016). This hypothesis might be condemned by those who have been responsible for the abuse of South Sudan's sovereignty, but it is a kind of bitter medicine, which they have to swallow, if South Sudan were to recover. As Lyman and Knopf (2016) have argued: "While a morally bankrupt and predatory elite will falsely characterise such an initiative as a violation of sovereignty, it is this very elite that has put the country's survival at risk."

Johnson (2014: 301) criticises the "fly-in-fly-out journalists" some of whom have described South Sudan largely in negative terms, claimed the country "became independent too early" and blamed this early independence on the USA. While I agree with the thrust of Johnson's argument, I understand why anyone would claim that South Sudan got independence too early, but I would not blame it on the USA alone. 
International society, including state and non-state actors, bears part of the responsibility for this development. Indeed, some of those negotiating for peace in South Sudan, including the AU and the UN, played roles in facilitating independence for South Sudan when its leaders were not ready to handle the responsibilities that came with independence. The former SPLM leader, the late John Garang, was circumspect about independence, but Kiir was determined to go for independence following Garang's death in a helicopter crash in July 2005. Due to several decades of neglect under Khartoum's rule, coupled with many years of civil war, and the unreliability of political leaders including Machar, the country had not built the human and institutional capacity required to govern a modern state (de Waal 2007). It lacked the capacity to exercise its sovereignty adequately. The leading political figures, including Garang, Kiir, and Machar, were more experienced in fighting wars than in building state institutions or crafting a political consensus outside the neo-patrimonial system (de Waal 2014b).

It could be argued that several generations of the South Sudanese population have seen more war than peace since the end of the AngloEgyptian condominium in the mid-1950s. They witnessed the Anya Nya guerrilla war of 1956-1972 when the south sought to secede after its demand for a federal system had been rejected (Johnson 2011; and Woodward 1989). They enjoyed a certain level of autonomy between 1972 and 1983. And then, there was another civil war spearheaded by the SPLM and its military wing, the SPLA, from 1983 to 2004. The fighting ended after the Comprehensive Peace Agreement (CPA), which was negotiated between the Khartoum government and the SPLM in Kenya, and was concluded in early 2005. The CPA, which demonstrated some readiness on the part of the AU to interpret sovereignty more flexibly, established a political-legal framework within which Khartoum and South Sudan could negotiate their future peacefully, but some of its provisions have not been honoured, thereby generating some uncertainty. There are, indeed, three sets of variables, which, among other tribulations, have combined to weaken South Sudan's sovereignty: bad governance, outstanding CPA issues, and the mismanagement of natural resources. South Sudan faces many problems, which cannot be resolved in a few years, but if these three sets of variables were addressed satisfactorily, the country would be stable, secure, and genuinely sovereign (de Waal \& Mohammed, 2014).

To answer the questions raised earlier and elaborate on my hypotheses, I have divided the remaining part of this article into four sections. In the first section I discuss the nature of sovereignty and explain how it could be 
applied to South Sudan. In the second section, I look at bad governance in South Sudan and explain how it has contributed to the undermining of sovereignty. In the third section I examine the CPA and explain how it relates to sovereignty, while in the fourth section I address issues relating to state-building and natural resource management. I conclude that a lasting peace might require a renegotiation of South Sudan's sovereignty and cogovernance arrangements for a limited period.

\section{Explaining sovereignty}

Writing in the 1990s, Francis Deng, who later became South Sudan's ambassador to the United Nations, with colleagues, defined sovereignty in terms of state responsibility, legitimacy, good governance, accountability, and the protection of citizens. They, for instance, argued:

[S]overeignty carries with it certain responsibilities for which governments must be held accountable. And they are accountable not only to their national constituencies but ultimately to the international community. In other words, by effectively discharging its responsibilities for good governance, a state can legitimately claim protection for its national sovereignty (Deng, et al 1996: 1).

A year earlier, Deng had argued: "In most cases, the collapse of the state is associated with humanitarian tragedies resulting from armed conflict, communal violence, and gross violations of human rights that culminate in the massive outflow of refugees and internal displacement of the civilian populations” (Deng 1995: 207). Most poignantly, Deng (1995: 207) added: "It is the lack or loss of capacity to cope with the crisis that leads to the collapse of the state and necessitates the intervention of the international community..." Much of what Deng and his colleagues claimed in the 1990s came to be reflected in the crises that engulfed South Sudan nearly two decades later.

Sovereignty is considered an important aspect of any state's internal governance and international relations, but it has no single or scientific definition (Weiss \& Chopra, 1995; Jackson 1999). While some scholars imply that it is one of the least contentious terms in political science (Walker 1990), others have argued that it is one of the most confusing concepts (James 1984; Kratochwil 1995). Whatever controversies exist, sovereignty is universally recognised as the primary constitutive principle of the modern state, but its history has not been properly explained. Since the 1648 treaties of Westphalia, sovereignty has evolved in response to the expansion of international society and the changing norms of global 
governance (Krasner 1999). In absolutist Europe, sovereignty was interpreted in authoritarian terms because the political leaders, who were not accountable to anyone, were believed to have been ordained by God (Philpott 2001; Makinda 1998a). However, in Africa, where all states achieved sovereign statehood through self-determination (Bruce-Wallace 1985), absolutist sovereignty has had no normative basis. Unfortunately, leaders of some independent African states have acted as if they were operating in absolutist Europe or some precolonial African societies. South Sudan is among few countries in which the constitution states explicitly that sovereignty belongs to the people. Its Constitution (2011) states: "Sovereignty is vested in the people and shall be exercised by the State through its democratic and representative institutions established by this Constitution and the law.” A little more than a decade before South Sudan's independence, Christopher Clapham (1996) had explained meticulously how African political leaders had subverted the conventions designed to uphold sovereignty with a view to pursuing their own selfish ends. As recent developments have demonstrated, South Sudan's political leaders have violated these conventions many times and left people wondering whether sovereignty resides with them or with the rulers.

To demystify sovereignty in Africa and the way it would apply to South Sudan, I would like to delineate three dimensions of sovereignty, which should be viewed like a three-legged traditional African stool. If one of the three legs breaks off, the stool will not serve its purpose unless the broken leg is restored. The first dimension of sovereignty is juridical, which is based on the notion that the state has no other authority over it except that of international law. South Sudan is a member of the UN and other international organisations by virtue of its juridical sovereignty. It is juridical sovereignty that has enabled it to establish diplomatic relations with other countries. It is also juridical sovereignty that makes it possible for President Kiir to be accorded respect by other states around the world. This juridical sovereignty was conferred on South Sudan at independence by international society. The inter-subjective understandings that accompany the conferring of juridical sovereignty to any state include the implicit message that the state in question would consolidate the other two dimensions of sovereignty. Moreover, international society continues to reinforce South Sudan's juridical sovereignty every time it acknowledges this country as an independent entity. If, for any reason, international society decided that South Sudan, or any state, should not remain juridically sovereign, it could take away that state's sovereignty. This happened in the early 1970s when the the US and the Soviet Union masterminded the denial 
of juridical recognition to Taiwan in terms of its loss of status as the official representative of China at the UN. (Makinda 2009; de Lisle 2011).

The second type of sovereignty is empirical, which is based on the notion that states have the right and ability to control the people, resources, and other entities within their borders. Empirical sovereignty is not directly conferred on states by international society. It is demonstrated through a country's political, economic, and military capacity to manage its internal affairs. One African country that has been deficient in empirical sovereignty for decades is Somalia (Bruce-Wallace 1997; Makinda 1993). South Sudan's claim to empirical sovereignty is highly doubtful. By failing to protect its own citizens when they were massacred in late 2013 and the time of this writing, South Sudan demonstrated that it lacked empirical sovereignty. Thus, one of the three legs of its stool appears to be broken. Whenever political leaders and government representatives refer to 'state sovereignty', they imply both juridical and empirical sovereignty. Jackson (1986) once referred to state sovereignty in Africa as 'negative' or quasisovereignty because many African states, which were juridically sovereign, lacked the empirical dimension to sovereignty.

The third dimension of sovereignty is popular, which is predicated on the claim that all citizens are equal and entitled to fundamental freedoms, and that governments control them only with their consent. Former UN Secretary-General Kofi Annan told the General Assembly in 1999 that by popular sovereignty, he meant "the fundamental freedom of each individual, enshrined in the Charter of the UN and subsequent international treaties" (UN Press Release 1999). While some commentators have associated the origin of popular sovereignty with Annan and his predecessor, Boutros Boutros-Ghali, this dimension of sovereignty can be traced back to John Locke, Jean Jacques Rousseau, and Thomas Paine, among others. Moreover, before Boutros-Ghali and Annan, former UN Secretary-General Javier Perez de Cuellar had claimed in 1991 that sovereignty needed to be re-assessed in response to "the shift in public attitudes towards the belief that the defence of the oppressed in the name of morality should prevail over frontiers and legal documents” (UN Press Release 1991). Thus popular sovereignty rests on the recognition of human rights (Mutua 1995; Makinda 2005). It is about the ability of citizens to hold their governments accountable. This suggests that human rights and state sovereignty need not be antagonistic; they should be regarded as parts of the same entity. On this issue, Makinda and Okumu (2008: 17) have observed: "As African states achieved independence on the basis of selfdetermination, which is universally recognised as a collective right, it is 
popular sovereignty that produced African independence." Thus, it is popular sovereignty that underpinned South Sudan's sovereign statehood and any time the South Sudanese leaders undermine human rights, they weaken their sovereignty.

On the basis of the above explanations, it is plausible to argue that South Sudan's current crisis has undermined empirical and popular sovereignty. Only juridical sovereignty, which is conferred by international society, has remained intact. Most of the damage to empirical and popular sovereignty has stemmed from bad governance.

\section{Bad Governance}

Good governance is crucial for the management and maintenance of sovereignty in any state, while its corollary, bad governance, has the potential to undermine and retard empirical and popular sovereignty. Recent political developments in South Sudan have demonstrated that in this country bad governance is the norm rather than an exception. While I have strong reservations about the way Riek Machar has gone about seeking political power, I agree with a statement he made in an interview with Asharq al Awsat on 2 January 2014, where he said: “.... lack of good governance is at the root of our problems" (Sirri 2014).Unfortunately, Machar and Kiir are among the main perpetrators of bad governance in South Sudan. They perpetuated a patron-client structure and repeatedly demonstrated that they are incapable of providing transformative leadership. Good governance is often a result of strategic vision, transformative leadership, effective institutions, and clear mechanisms to ensure that the rule of law and human rights are respected. Kiir and his ministers often issue platitudes about unity, development and peace, but there is no substance to what they say. This lack of a shared strategic vision has, in turn, resulted in poor and misguided policies. Kiir was elevated to leadership, following Garang's death in 2005, on the basis of his martial prowess, not political acumen. Fighting a war is one thing, but building a state and ruling it for the benefit of its people is another. Kiir, who spent more than two decades fighting a guerrilla war, could not manufacture a liberal democracy out of nothing. It is Kiir, Machar and other senior members of South Sudan's political elite that have presided over the abuse of sovereignty.

African nationalist leaders who assumed power after independence in the 1950s and 1960s, such as Kwame Nkrumah of Ghana and Jomo Kenyatta of Kenya, were not under global scrutiny and could mismanage their countries without major voices in international society protesting (see 
Makinda 2013). At that time, what counted most were territorial integrity and juridical sovereignty. Empirical and popular sovereignty were ignored. This was partly because international society defined sovereignty primarily in terms of the territorial norm (Barkin \& Cronin 1994). However, since the end of the Cold War, international society has increasingly defined sovereignty in terms of the democratic norm (Makinda 1998b). This is why Franck (1992) hypothesised about the global impact of the emerging democratic norm in the early post-Cold War period. Thus, South Sudan became independent when democracy was regarded as an entitlement for everyone and political leaders were expected to meet certain standards of accountability. Moreover, the AU adopted the charter on democracy, elections and governance in January 2007. Unfortunately, leaders who have no experience in democratic rule, or who have known little but war for two decades, would find it difficult to meet the governance standards expected of them. In this case, international society needed to provide South Sudanese leaders with some guidance prior to allowing them to handle the responsibilities that were placed on their shoulders. The majority of the South Sudanese population have not experienced liberal democracy and have not been given opportunities to exercise many of their rights and responsibilities. Had South Sudan been placed under an international administration for a few years, similar to that under which Timor Leste operated from 2000 to 2002, the political outcome would probably have been different (Martin 2001). The South Sudanese people would have had a chance to build democracy from the ground up. This would, in turn, have buttressed empirical and popular sovereignty. Instead, these two dimensions of sovereignty have repeatedly been damaged by various factors, including the ruling party, the military, and rampant corruption.

One way in which the ruling party, SPLM, undermined empirical and popular sovereignty in South Sudan was through its failure to transform itself from a national liberation movement into a political party with the core values of democracy, justice and nationalism. The SPLM still appears to be guided by the guerrilla approach to issues, and this is one of the sources of the political crisis. In relation to SPLM dynamics, de Waal (2014a: 348) argues that South Sudan's neo-patrimonial system condones conditions in which "political office is used primarily for personal and factional advantage”. Democracy, which underpins good governance, is possible only if the structures, processes and institutions through which the people's will is expressed have been internalised (Makinda 1996). There is no evidence that the SPLM has sought to involve the South Sudanese people in governance. Kiir's appointment of Taban Deng Gai in July 2016 
to replace Machar as senior Vice-President illustrated the lack of accountability in the political system.

Like the SPLM, the SPLA, led by Paul Malong Awan since April 2014, has not transformed itself into a modern military force (Pinaud 2014). It remains an umbrella of warlords and armed groups who are loosely controlled from the top. Many of these warlords have been leasing their troops in return for rent for several decades. Now that they are part of the SPLA, they needed to demonstrate full commitment to a united South Sudan. The SPLA undermined empirical and popular sovereignty through its weak structure and its lack of cohesion, which, in turn, made it possible for various warlords to withdraw their contingents from the SPLA and declare themselves autonomous, after which they may be able to renegotiate a better deal before being reincorporated into the SPLA. On some occasions, SPLA factions have undertaken cross-border operations without approval from the government in Juba. A case in point was the unexpected invasion of Heglig in Sudan by one of the SPLA factions in March 2012 while Kiir was in Beijing (Shaib 2012). This was done without Kiir's approval, and their intention was not necessarily to hold onto Heglig, but to make it one of the bones of contention. South Sudan and Khartoum agreed in March 2013 to withdraw troops from the border area and establish a demilitarised zone, but it was not clear whether all factions within the SPLA would respect it. As de Waal (2014a: 348) has explained, the neopatrimonial system in South Sudan is militarised, thereby enabling the "contending members of the elite... [to] use force or the threat of force as an instrument of bargaining".

The way the SPLM and the SPLA have operated has illustrated two factors in relation to empirical and popular sovereignty. The first is that the top leadership in the government has had very little control over two key national institutions: the ruling party and the military. The second is that the mechanisms through which the people of South Sudan could hold their government accountable are absent.

Another way in which bad governance has undermined empirical and popular sovereignty is that public institutions remain weak and some have no institutional memory. It is common for senior civil servants to work on important projects and leave no records behind for their successors. This approach has led to two undesirable consequences. The first is that the elevation of individuals above institutions has made South Sudanese civil servants align their office tenure with key individuals in the government. Once these key individuals, such as Machar, are removed, those who are 
aligned with them begin to feel vulnerable. This practice has destroyed the ground on which empirical and popular sovereignty would be anchored.

With the ruling party, the military and major public institutions in disarray, it is not surprising that senior public officials have frequently abused the power entrusted in them and used government resources for private gain. According to various sources, including Transparency International, corruption in South Sudan has permeated all sectors of the economy and all levels of state and national government (U4 Anticorruption Resource Centre 2013). Corruption in South Sudan has been an indicator of the abuse of empirical and popular sovereignty, and of the failure to build a viable and functional state. The institutionalisation of the corruption culture has reached the point where citizens are commonly asked for bribes when they seek access to various public services, and they have come to expect it. This practice is largely due to the greed of political leaders and underpins the weakening of empirical and popular sovereignty.

Kiir underlined the rampart nature of corruption in a letter dated 3 May 2012 and addressed to 75 former and serving government officials, in which he complained that US\$4 billion had been stolen and promised to give amnesty to those who returned the money (Holland 2012). He stated how corruption undermines popular sovereignty when he stated: "We fought for freedom, justice and equality... Yet, once we got to power, we forgot what we fought for and began to enrich ourselves at the expense of our people" (Holland 2012). According to various sources, most of the revenue from oil does not end up in Juba, but in the foreign bank accounts of the ruling elite (de Waal 2014a). This is made easy by the fact that a very high percentage of South Sudan's government officials have their families in neighbouring states and other foreign countries. Another way of stealing government resources is to pay salaries to 'ghost' workers. It is a system through which some civil servants draw the second salary through a 'ghost' employee. This issue is so serious that in 2010, a South Sudanese cabinet minister told a workshop organised jointly by the South Sudan government and USAID that 'ghost' workers were a major factor in corruption (DFID 2013).

In a 2013 report on anti-corruption in South Sudan, the UK Department for International Development cited a perception survey conducted by the South Sudan Anti-Corruption Commission in 2011. The survey concluded that 96 percent of respondents felt that corruption was common, with 97 percent of them regarding it as a 'serious' or 'very serious' problem. Many international partners of South Sudan directly spend their money rather than giving it to the government, and this reduces the chances of donor funds 
being stolen (DFID 2013). Such a practice also underlines the point that empirical and popular sovereignty have been undermined. The weakness in sovereignty has been exacerbated by the seriousness of outstanding CPA issues.

\section{Outstanding CPA issues}

Several issues connected with the CPA had a major impact on both the weakening of sovereignty and the continuation of the political crisis. One of them was the failure by both Khartoum and the SPLM to honour some of the key provisions of the CPA. Another was the failure of international society to ensure that both parties to the CPA provided an enabling environment for its implementation. The CPA was negotiated under the auspices of IGAD, with considerable input from the UN, the US, the UK, Italy, and Norway. The document was revolutionary in light of African diplomatic practice in at least two senses. In the first sense, it legitimised the suspension of the then sacrosanct 1964 Organisation of African Unity (OAU) Cairo declaration, which prohibited the change of African state boundaries as they existed at the time of independence. ${ }^{3}$ It provided room for all those involved to contemplate the reconstruction of Khartoum's sovereignty. In the second sense, the CPA illustrated that if there was political will on the part of international society, the juridical sovereignty of African states could be reconsidered in efforts to enhance popular sovereignty.

The CPA was premised on universal values and norms that are crucial for the realisation of empirical and popular sovereignty: peace, justice, security, stability, and development. Every chapter and section of the CPA reiterates these norms and emphasises why they are important for the people of Khartoum and South Sudan. To the extent that the CPA promised empirical and popular sovereignty explicitly and suggested juridical sovereignty for South Sudan only implicitly, it could be argued that for South Sudan, empirical and popular sovereignty were primary goals. In the context of the CPA, juridical sovereignty for South Sudan was a secondary goal. For this reason, international society would be acting irresponsibly if it honoured South Sudan's juridical sovereignty without question after its leaders have betrayed the empirical and popular sovereignty promised in the CPA.

3 Eritrea also gained independence from Ethiopia in the early 1990s under similar circumstances. 
The CPA was also predicated on specific issues: power sharing between the Khartoum government and the SPLM; wealth sharing; the resolution of the Abyei conflict; the resolution of the Southern Kordofan and Blue Nile conflicts; and security arrangements. These issues also reinforce the above values. For example, section 1.4.5 of the power sharing agreement refers to the "Pursuit of good governance, accountability, transparency, democracy, and the rule of law at all levels of government to achieve lasting peace" (CPA 2005: p. 12). Very few of these issues have been fully addressed, with both parties to the CPA blaming each other for the stalemate.

Regarding security sector reforms, the CPA called for the incorporation of other armed groups into Khartoum's armed forces or the SPLA, but some militias still remain outside the two military organisations. Moreover, Khartoum and South Sudan have signed non-aggression pacts and pledged to respect each other's sovereignty and territorial integrity, but their armed forces exchange fire frequently. However, given the fact that Kiir's government does not have full control over all elements of the SPLA, it has not been easy for observers to tell whether the SPLA units firing at Khartoum's forces have officially been authorised by the government or not. Under these circumstances, South Sudan is unlikely to achieve internal stability and pay attention to its development agenda unless it pursues security sector reforms successfully. The inability to pursue security sector reforms successfully is partly due to the weakening of empirical sovereignty.

This weakness in empirical sovereignty has been demonstrated through South Sudan's failure to control militia groups that operate across the border into Sudan, especially in Southern Kordofan and Blue Nile states. It is generally acknowledged that several militia groups, especially the Nuba, in Southern Kordofan and Blue Nile, fought alongside the SPLA between 1983 and 2004. However, the CPA placed them in Sudan. Moreover, under the CPA, the Khartoum and Juba governments agreed that they would ascertain the views of the people of these states through popular consultation. Due to cross border attacks, the Khartoum government has accused South Sudan of supporting rebel militia groups in the two states, but the South Sudanese government has repeatedly denied the accusations.

One of the most contentious CPA outstanding issues relates to the region of Abyei, which is on the border between South Sudan and Sudan. It produces oil, but that is not its main significance to some South Sudanese policy-makers. Abyei is home to nine influential Ngok Dinka chiefdoms, which were transferred to Kordofan by the British colonial authorities back in 1905. Some of South Sudan's most influential politicians come from the 
region. The CPA specified the boundaries of Abyei and called for a referendum to determine whether Abyei should be part of Sudan or South Sudan. The region was expected to hold the referendum in January 2011, but Khartoum and South Sudan disagreed over several matters. The referendum has been put off indefinitely, a fact that illustrates how Khartoum and South Sudan have frustrated efforts to achieve popular sovereignty. Disagreements over voter eligibility revolve around Abyei's two major ethnic groups: the farming group, namely Ngok Dinka, who would like to join South Sudan and the nomadic cattle-herding group, Misseriya, who would like to join Khartoum and be located in Sudan. South Sudan claims that the Misseriya, who graze their cattle in the region only during the dry season, should not vote. However, Khartoum insists that this group has to participate in the referendum. Although the CPA guarantees the grazing rights of the Misseriya irrespective of where Abyei would go, the Misseriya have threatened war if they do not participate in the referendum. ${ }^{4}$

This problem and other CPA outstanding issues result from bad governance in both South Sudan and Khartoum (Young 2012). They also serve to weaken empirical and popular sovereignty. As long as these problems remain, the South Sudanese leadership is unlikely to give adequate attention to the development agenda, economic management and the effective use of its oil revenues.

\section{State-building and the management of natural resources}

South Sudan's sovereignty has further been weakened by the lack of serious attention to state-building, coupled with misguided policies in resource management. In recent analyses of African economic performance, various authors have argued and provided statistics to prove that African economies are rising (Economist 2013; Swaniker 2013; Scott 2016). Unfortunately, South Sudan's is not one of the rising African economies. South Sudan faces a daunting task of building the nation and harnessing its resources to benefit the people. Due to many decades of marginalisation that go back to the colonial period, the country has a shortage of teachers, classrooms, doctors, nurses, and expertise in many areas of the public

\footnotetext{
${ }^{4}$ Some South Sudanese politicians disagree with their counterparts in Khartoum over the original boundaries of Abyei. They also have a different view of the span of the Ngok Dinka chiefdoms in Abyei. These divergent positions occasionally served as a source of friction between Khartoum and South Sudan, especially following the signing of the CPA.
} 
service. Despite the oil revenues, the country remains among the least developed in Africa. South Sudan relies heavily on agriculture, but it has been estimated that less than 5 percent of the country's arable land is under cultivation. The territory has few industries that can generate jobs, and as a result, unemployment is high and still rising. It needs huge investments, especially in infrastructure and agriculture, but many international investors are reluctant to go in because of high political and security risks compared to its neighbours, particularly Ethiopia, Kenya, and Uganda. It is hard for South Sudan to attract investors into the country while the political elite is grabbing whatever resources are available and investing them in the neighbouring countries (see The Sentry 2016).

The country's major export commodity is oil, but the fall in oil prices since 2014 has reduced government revenue considerably. South Sudan has the third largest oil reserves in Sub-Saharan Africa, but continuing disputes over it have hindered further investments in the sector. There have been continuing disputes between Khartoum and South Sudan, between the South Sudanese government and the oil companies, and between the central government in Juba and various state governments. Since Chevron discovered oil fields near Bentiu in the Unity state of South Sudan in 1978, the Khartoum government and South Sudanese politicians have disagreed on how to develop, refine and export the commodity, and on how to share the revenue from it. The South Sudanese leaders were opposed to the construction of refineries in the north and of a pipeline to Port Sudan on the Red Sea for the export of crude oil. About 75 percent of the oil comes from South Sudan, but all the pipelines run through Sudan. Since its independence in July 2011, South Sudan has been exploring the possibilities of exporting oil through its other neighbours, including Kenya, Djibouti and the Central African Republic, rather than continuing to depend on a hostile Khartoum government. One could argue that it is in the interest of South Sudan to diversify its relationships with neighbours. However, such a move would require considerable investment in infrastructure, which is unlikely to take place under the present circumstances. In addition, the abandonment of Khartoum's pipelines would have serious legal implications, which might require South Sudan to compensate both Khartoum and the corporations that constructed the pipelines (see Kibe and Kimenyi 2013).

The CPA stipulated that oil revenue would continue to be shared equally between Khartoum and South Sudan for the duration of the agreement. However, South Sudan lacks the capacity to ensure that the oil revenue benefits its citizens. Since independence, the South Sudanese government 
has renegotiated with Khartoum over the distribution of oil revenues. The fact that Khartoum benefits from South Sudan's exportation of oil has narrowed the range of foreign investors in the sector. Due to US sanctions against Khartoum, US corporations have not invested in South Sudan's oil sector for fear of benefiting the Khartoum regime and thereby violating the sanctions. As a result, the main investors in this sector are from China, India and Malaysia. While it is tempting to focus on the future oil production when assessing South Sudan's prospects, it is hard to see how oil revenues will benefit the people of South Sudan under the current circumstances. In the light of recent financial scandals, and given the lack of accountability on the part of senior government officials, most of the oil revenue will continue to be misappropriated. The answer lies in the enhancement of empirical and popular sovereignty through state-building and effective resource management infrastructure.

In the meantime, it is unrealistic for international society to expect South Sudan to address its multiple-layered problems with its current infrastructure and human resource base. The current political crisis is a demonstration of South Sudan's inability to establish an enabling environment required for nation-state building. It is also a signal that now is the time to renegotiate the country's sovereignty.

\section{Conclusions: co-governance could work}

Many of South Sudan's problems may not be addressed satisfactorily without reference to the serious weakness in the country's sovereignty. The political crisis that erupted in December 2013 and which continues to the time of this writing in 2017, is partly a reflection of the failure of international society to ensure that South Sudan was appropriately guided to the stage where it would become a viable and functioning state with the capabilities to protect its citizens and provide them with essential services. It is also partly a failure of the South Sudanese leadership to build a new nation-state and govern it well, to negotiate seriously outstanding CPA issues, and to manage the oil wealth as a public good. Above all, it is a failure by South Sudan's leaders and international partners to place the people of South Sudan at the centre of their strategies. Ultimately, it is a call for the renegotiation of South Sudan's sovereign statehood and the creation of co-governance arrangements (which cannot be prescribed in this short article), which should be worked out between South Sudan's representatives, the AU, IGAD, the UN and South Sudan's international partners. Whether Kiir and Machar remain in political leadership should depend on an assessment of their potential contribution to good governance. 
The root causes of South Sudan's political crisis comprise poor political leadership, a malfunctioning state, the lack of an enabling environment, and the complicity of international society in the practices that are taking place there. The political crisis has given international society an opportunity to take bold measures, including the construction of co-governance arrangements. As it has already been demonstrated, South Sudan lacks empirical and popular sovereignty. It has juridical sovereignty only because international society has consented to it. Renegotiating sovereignty and creating co-governance arrangements would not constitute a recolonisation of the country. Neither would it mean a UN trusteeship, which would be prohibited by Article 78 of the UN Charter (UN Charter 1945). Renegotiating sovereignty would entail establishing co-governance arrangements designed to ensure that the South Sudanese people enjoy security and popular sovereignty while the country's public institutions are reconstructed.

In a recent article, Lyman and Knopf (2016) argued that the most effective way for international society to help the people of South Sudan is to "put South Sudan on 'life support' by establishing an executive mandate for the UN and the AU to administer the country until institutions exist to manage politics non-violently and break up the patronage networks underlying the conflict”. These two former US officials are primarily prescribing co-governance arrangements, which could see South Sudan build the institutions it needs for peace, security and development.

The AU would need to take a leading role in the co-governance of South Sudan. While the framers of the Constitutive Act of the AU (CAAU) did not anticipate that there would be a need for co-governance in any of its members, if there was political will on the part of the AU leadership, the Union could establish such an arrangement utilizing some sections of the CAAU. For example, Article 4(h) of the CAAU gives the Union the right to intervene in a member state "in respect of grave circumstances, namely: war crimes, genocide and crimes against humanity”. Moreover, Article 4(j) of the CAAU gives member states the right to request intervention from the $A U$ "in order to restore peace and security". On the basis of these two sections of the CAAU, the South Sudan government could request the AU to intervene. If it does not do so, the AU could invoke Article 4(h) and intervene. Just as the AU interpreted its Constitutive Act flexibly to allow South Sudan to secede, it could interpret it again flexibly to establish a cogovernance arrangement in South Sudan.

There have been cases elsewhere in the past few decades where sovereignty has been renegotiated and co-governance arrangements 
established. A good example is Cambodia whose sovereignty was renegotiated in the early 1990s after it had previously been split into two, with the Vietnamese-backed Heng Samrin regime exercising empirical sovereignty while the exiled and Western-backed Coalition Government of Democratic Kampuchea, which included the notorious Khmer Rouge, exercised juridical sovereignty. The UN Transitional Authority in Cambodia (UNTAC) was part of the co-governance arrangements. A senior member of UNTAC told me at the time that had it not been for UNTAC, certain important democratic measures, including the preparation of the electoral roll, would not have been accomplished. By the time UNTAC concluded its mission in 1992, peace had been restored and all dimensions of Cambodian sovereignty had been united. This was made possible by the compromises of Cambodia's political factions as well as the key roles played by regional and global actors (Doyle 1995; Makinda 2001).

Renegotiating South Sudan's sovereignty, and creating co-governance arrangements for a limited period, would deliver good governance, strengthen economic management, facilitate state building, and enhance regional security. It might be the best way to break the cycle of violence and restore power to the people in this oil-rich country.

\section{References}

Barkin, S. J. \& Cronin, B. (1994). 'The State and the Nation: Changing Norms and Rules of Sovereignty', International Organization 48 (1): 107-130.

Bruce-Wallace, N. L. (1985). 'Africa and International Law - the Emergence of Statehood', Jnl of Modern African Std, 23 (4):575-602

Bruce-Wallace (1997). 'Taiwan and Somalia: International Legal Curiosities', Queen's Law Journal, 22 (2): 453-485.

Bull, H. (1977). The Anarchical Society. London: Macmillan.

Clapham, C. (1996). Africa and the International System. Cambridge: Cambridge University Press.

Constitution of South Sudan, Part 1, article 2: www.sudantribune.com/ IMG/pdf/The_Draft_Transitional_Constitution_of_the_ROSS2-2.pdf

CPA: The Comprehensive Peace Agreement (2005), The Comprehensive Peace Agreement between the Government of the Republic of Sudan and the Sudan People's Liberation Movement/Sudan People's Liberation Army (Nairobi, Kenya).

Deng, F. M. (1995). 'State Collapse: The humanitarian challenge to the United Nations' in I. William Zartman, (Ed). Collapsed States: The 
disintegration and restoration of legitimate authority. Boulder, CO: Lynne Rienner, 207-219.

Deng, F. M., S. Kimaro, T. Lyons, D. Rothchild and I. W. Zartman, (1996). Sovereignty as Responsibility: Conflict management in Africa. Washington, DC: The Brookings Institution.

DFID, (2013). Department for International Development, 'DFID's AntiCorruption Strategy for South Sudan.' https://www.gov.uk/gov ernment/.../anti-corruption-strategy-ss.pdf

Doyle, M. W. (1995). UN Peacekeeping in Cambodia: UNTAC's Civil Mandate. Boulder, CO: Lynne Rienner.

Economist, The (2013). 'Africa rising: A hopeful continent'. www.economist.com/news/special-report/21572377-african-liveshave-already-greatly-improved-over-past-decade-says-oliver-august

Franck, T. M. (1992). 'The Emerging Right to Democratic Governance', The American Journal of International Law 86 (1): 46-91.

Holland, H. (2012). 'South Sudan officials have stolen \$4 billion: president', Reuters. http://www.reuters.com/article/2012/06/04/ussouthsudan-corruption-idUSBRE8530QI20120604

IGAD (Intergovernmental Authority on Development) (2015). Agreement on the Resolution of the Conflict in the Republic of South Sudan (Addis Ababa, Ethiopia).

Jackson, R. H. (1986). 'Negative Sovereignty in Sub-Saharan Africa', Review of International Studies 12 (4): 247-264.

James, A. (1984). Sovereign Statehood: The Basis of International Society. London: Allen and Unwin.

Johnson, D. H. (2011). The Root Causes of Sudan's Civil Wars: Peace or Truce. Revised edn. Oxford: James Currey.

Johnson, D. H. (2014). 'Briefing: The Crisis in South Sudan', African Affairs 113 (451): 300-309.

Kibe, J. \& Kimenyi, M. S. (2013). 'Is South Sudan on the Verge of Collapse?' http://www.brookings.edu/blogs/up-front/posts/2013/08/ 20-south-sudan-kimenyi

Krasner, S. D. (1999). Sovereignty: Organized Hypocrisy. Princeton: Princeton University Press.

Kratochwil, F. (1995). 'Sovereignty as Dominium: Is There a Right of Humanitarian Intervention?', in G. M. Lyons \& M. Mastanduno, (Eds). Beyond Westphalia? State Sovereignty and International Intervention. Baltimore, MD: Johns Hopkins Uni Press, 21-42.

Lisle, J. de (2011). 'Taiwan: Sovereignty and Participation in International Organizations’, Foreign Policy Research Institute, Uni Pennsylvania: 
http://www.fpri.org/articles/2011/07/taiwan-sovereignty-andparticipation-international-organizations

Lyman, P and K. A. Knopf. (2016). 'To save South Sudan, put it on life support', Financial Times (July 20). http://blogs.ft.com/beyondbrics/2016/07/20/to-save-south-sudan-put-it-on-life-support/

Makinda, S. M. (1993). Seeking Peace From Chaos: Humanitarian Intervention in Somalia. Boulder, CO: Lynne Rienner.

Makinda, S. M. (1996). 'Democracy and Multi-Party Politics in Africa', Journal of Modern African Studies 34 (4): 555-573.

Makinda, S. M. (1998a). 'Sovereignty and Global Security', Security Dialogue 29 (3): 281-292.

Makinda, S. M. (1998b). 'The United Nations and State Sovereignty: Mechanism for Managing International Security', Australian Journal of Political Science 33 (1): 101-15.

Makinda, S. M. (2001). 'Security and Sovereignty in the Asia-Pacific', Contemporary Southeast Asia 23 (3): 401-419.

Makinda, S. M. (2005). 'Following postnational signs: the trail of human rights', Futures 37 (9): 943-957.

Makinda, S. M. (2009). 'Contesting Sovereignty', in A. Franceschet, Ed. The Ethics of Global Governance. Lynne Rienner: 21-34.

Makinda, S. M. (2013). 'Africa's Leadership Malaise and the Crisis of Governance', in T. M. Shaw, K. Hudson \& G. Kararach, (Eds). Rethinking Development Challenges for Public Policy: Insights from Contemporary Africa. London: Palgrave, 54-82.

Makinda, S. M. \& Okumu, F. W. (2008). The African Union: Challenges of Globalization, Security and Governance. London: Routledge.

Martin, I. (2001). Self-Determination in East Timor: The United Nations, the Ballot, and International Intervention. Lynne Rienner.

Mutua, M. (1995). 'The Banjul Charter and the African Cultural Fingerprint: An Evaluation of the Language of Duties', Virginia Journal of International Law 35 (2): 339-380.

Philpott, D. (2001). Revolutions in Sovereignty: How ideas shaped modern international relations. Princeton: Princeton University Press.

Pinaud, C. (2014). "South Sudan: Civil War, Predation and the making of a military aristocracy”, African Affairs113 (451): 192-211.

Prendergast, J (2017). How the world's newest country went awry: South Sudan's war, famine, and potential genocide, www.enoughproject. org/files/SouthSudanAwry_March2017_EnoughProject.pdf

Scott, K. (2016). 'Optimism is rising in Africa, here is why', CNN. http://edition.cnn.com/2016/12/16/africa/optimism-in-africa/ 
Shaib, A. (2012). 'It's not just why Heglig, but why now?' Al Jazeera,www .aljazeera.com/indepth/opinion/2012/05/2012568179201627.html

Sirri, M. (2014). 'Riek Machar: Kiir wants to provoke a tribal war in South Sudan', Asharq al Awsat, http://www.aawsat.net/2014/01/article $\underline{55326416}$

Swaniker, F. (2013). 'Africa’s Rising Economies', Survival 55, 4: 129-142.

The Sentry (2016). War Crimes Shouldn't Pay: Stopping the looting and destruction in South Sudan. https://cdn.thesentry.org/wp-con tent/uploads/2016/09/Sentry_WCSP_Finalx.pdf.

U4 Anti-Corruption Resource Centre and Transparency International, 'Overview of corruption and anti-corruption in South Sudan' http://www.u4.no/publications/south-sudan-overview-of-corruptionand-anti-corruption/downloadasset/3034.

UN Press Release (1991). SG/SM/4560 (24 April).

UN Press Release (1999). SG/SM/7136 (20 September) http://www.un.org/press/en/1999/19990920.sgsm7136.html.

Waal, A. de \& Mohammed, A. (2014). 'Breakdown in South Sudan: What Went Wrong - and How to Fix It', Foreign Affairs http://www.foreignaffairs.com/articles/140617/alex-de-waal-andabdul-mohammed/breakdown-in-south-sudan

Waal, A. de, (Ed). (2007). War in Sudan and the Search for Peace. Cambridge, MA: Harvard University Press.

Waal, A. de (2014a). 'When Kleptocracy Becomes Insolvent: Brute causes of the Civil War in South Sudan', Afri Affairs 113 (452): 347-369.

Waal, A. de (2014b). 'Sudan: a turbulent political marketplace' in M. Kamrava, ed., Fragile Politics: weak states in the greater Middle East. London: Hurst \& Co.

Walker, R. B. J. (1990). 'Sovereignty, Identity and Community: Reflections on the Horizons of Contemporary Political Practice', in R. B. J. Walker and S. H. Mendlovitz, eds., Contending Sovereignties: Redefining Political Community. Boulder, CO: Lynne Rienner.

Weiss, T. G. \& J. Chopra (1995). 'Sovereignty under siege: From intervention to humanitarian space' in G. M. Lyons and M. Mastanduno, Eds., Beyond Westphalia? State Sovereignty and International Intervention. Baltimore, MD: Johns Hopkins University Press, 87-114.

Woodward, P. (1989). Sudan 1898-1989: The Unstable State. Boulder, CO: Lynne Rienner.

Young, J. (2012). The Fate of Sudan: The origins and consequences of a flawed peace process, London: Zed Press. 